\title{
(2E,5E)-2,5-Bis(3-hydroxy-4-methoxybenzylidene) cyclopentanone Exerts Anti-Melanogenesis and Anti-Wrinkle Activities in B16F10 Melanoma and Hs27 Fibroblast Cells
}

\author{
Hee Jin Jung ${ }^{1}$, A Kyoung Lee ${ }^{1,2}$, Yeo Jin Park ${ }^{1,2}$, Sanggwon Lee ${ }^{1,2}$, Dongwan Kang ${ }^{1,2}$, \\ Young Suk Jung ${ }^{1,2}$, Hae Young Chung ${ }^{1,2}$ and Hyung Ryong Moon 1,2,* (D) \\ 1 Molecular Inflammation Research Center for Aging Intervention (MRCA), Pusan National University, Busan \\ 46241, Korea; hjjung2046@pusan.ac.kr (H.J.J.); lak000@naver.com (A.K.L.); pyjin5526@gmail.com (Y.J.P.); \\ lsk3232@pusan.ac.kr (S.L.); 3607@pusan.ac.kr (D.K.); youngjung@pusan.ac.kr (Y.S.J.); \\ hyjung@pusan.ac.kr (H.Y.C.) \\ 2 College of Pharmacy, Pusan National University, Busan 46241, Korea \\ * Correspondence: mhr108@pusan.ac.kr; Tel.: +82-51-510-2815; Fax: +82-51-518-2821
}

Received: 11 May 2018; Accepted: 11 June 2018; Published: 11 June 2018

\begin{abstract}
Ultraviolet (UV) radiation exposure is the primary cause of extrinsic skin aging, which results in skin hyperpigmentation and wrinkling. In this study, we investigated the whitening effect of (2E,5E)-2,5-bis(3-hydroxy-4-methoxybenzylidene)cyclopentanone (BHCP) on B16F10 melanoma and its anti-wrinkle activity on Hs27 fibroblasts cells. BHCP was found to potently inhibit tyrosinase, with $50 \%$ inhibition concentration $\left(\mathrm{IC}_{50}\right)$ values of $1.10 \mu \mathrm{M}$ and $8.18 \mu \mathrm{M}$ for monophenolase (L-tyrosine) and diphenolase (L-DOPA), and the enzyme kinetics study revealed that BHCP is a competitive-type tyrosinase inhibitor. Furthermore, BHCP significantly inhibited melanin content and cellular tyrosinase activity, and downregulated the levels of microphthalmia-associated transcription factor (MITF), phosphorylated levels of cAMP response element-binding (CREB) protein, and tyrosinase in $\alpha$-melanocyte stimulating hormone ( $\alpha$-MSH)-induced B16F10 melanoma cells. Moreover, $\mathrm{BHCP}$ inhibited the phosphorylation of $\mathrm{p} 65$ and expression of matrix metalloproteinases (MMP-1, MMP-9, MMP-12, and MMP-13) in Hs27 fibroblasts stimulated with UV radiation. Therefore, our results demonstrate that BHCP may be a good candidate for the development of therapeutic agents for diseases associated with hyperpigmentation and wrinkling.
\end{abstract}

Keywords: (2E,5E)-2,5-Bis(3-hydroxy-4-methoxybenzylidene)cyclopentanone (BHCP); tyrosinase inhibitor; anti-melanogenesis; anti-wrinkle

\section{Introduction}

Skin aging is a complex and progressive process that leads to functional and aesthetic changes in the skin, with both intrinsic and extrinsic factors being responsible [1]. Extrinsic skin aging is caused by environmental aggressors, such as ultraviolet (UV) radiation, stress, or smoking. However, it is mainly caused by repeated exposure to UV from the sun, which is called photoaging. Skin photoaging is characterized by coarse and deep wrinkles, thickness, roughness, dyspigmentation, and histological changes [2-4].

Tyrosinase (EC 1.14.18.1), which is also known as polyphenol oxidase, is one of the multifunctional copper-containing enzymes involved in melanin synthesis and is found widely in nature [5]. Tyrosinase is typically present in a majority of microorganisms, plants, and animals. In plants, tyrosinase acts by oxidizing monophenols into diphenols (monophenolase activity) and is involved 
in the oxidation of $o$-diphenols into $o$-quinones (diphenolase activity), followed by the oxidation of quinones into dark-brown pigments [6].

Melanogenesis is the transformation of L-tyrosine into 3,4-dihydroxyphenylalanine (L-DOPA), whereby L-DOPA is converted into DOPA quinine [7]. Hence, tyrosinase plays an important role in melanin production in melanocytes, and the inhibition of tyrosinase is an attractive target for the improvement of pigmentation-related disorders and for the development of whitening agents [8,9]. Melanin synthesis is induced by several stimuli, such as UV and chemicals including isobutylmethylxanthine (IBMX) and alpha-melanocyte-stimulating hormone ( $\alpha$-MSH). $\alpha$-MSH binds to its receptor melanocortin 1 receptor (MC1R), subsequently increasing the cytoplasmic cyclic AMP (cAMP) level. The increased cAMP level activates protein kinase A (PKA), which induces the expression of microphthalmia-associated transcription factor (MITF) via phosphorylation of the cAMP response element-binding protein (CREB). MITF induces the expression of tyrosinase, tyrosinase-related protein (TRP)-1, and TRP-2, which finally results in increased melanin synthesis [10]. MITF is considered a key transcription factor of melanogenesis; therefore, many studies have been performed to control the expression of MITF to inhibit melanogenesis [11].

Wrinkle formation is known to be closely associated with the degradation of the extracellular matrix of the skin, and UV radiation activates nuclear factor- $\mathrm{kB}(\mathrm{NF}-\mathrm{kB})$, thereby increasing the production of collagen fragmentation and matrix metalloproteinases (MMPs) [2]. MMPs are zinc-dependent endopeptidases that are important in the remodeling of the extracellular matrix structure in skin. Therefore, the excessive degradation of collagen and the matrix by UV-induced MMPs is a characteristic feature of photodamaged skin, and MMPs are used as a major marker of UV-induced photoaging as well as skin inflammation [12].

The curcumin-like diarylpentanoid skeleton derivatives have been reported to exhibit a wide range of bioactivities, including antioxidant, anticancer, anti-inflammation, anti-melanogenesis, and anti-tyrosinase [13-18] activities. Especially, Leow et al. [19] reported in 2014 that dibenzylidene-cyclopentanone scaffolds, including (2E,5E)-2,5-bis(3-hydroxy-4-methoxybenzylidene)cyclopentanone (BHCP) (Figure 1), might contribute to the protective effects on human osteosarcoma via regulation of the $\mathrm{Wnt} / \beta$-catenin signaling pathway. However, the anti-melanogenesis and anti-wrinkle effects of $\mathrm{BHCP}$ remain to be discovered, and the molecular mechanisms underlying its activity have not yet been clearly established.

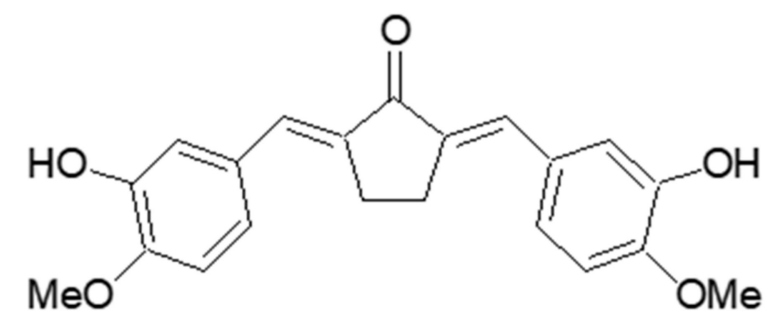

Figure 1. Structure of (2E,5E)-bis(3-hydroxy-4-methoxybenzylidene)cyclopentanone (BHCP).

In the present study, we investigated the anti-melanogenesis and anti-wrinkle potential of BHCP, and sought to identify the mechanism involved, especially with respect to melanin content and cellular tyrosinase activity, which were explored using tyrosinase inhibition assay and analysis of enzyme kinetics. Moreover, we demonstrated that BHCP exerts an inhibitory effect on melanogenesis and wrinkles that is associated with the downregulation of CREB/MITF/tyrosinase in $\alpha$-MSH-induced B16F10 mouse melanoma cells and inhibition of phosphorylation of p65 and MMP expression in UV-induced Hs27 human fibroblasts. 


\section{Results and Discussion}

\subsection{Synthesis of (2E,5E)-2,5-Bis(3-hydroxy-4-methoxybenzylidene)cyclopentanone (BHCP)}

A solution of 3-hydroxy-4-methoxybenzaldehyde (100 $\mathrm{mg}, 0.66 \mathrm{mmol}$, isovanillin) and cyclopentanone $(0.03 \mathrm{~mL}, 0.33 \mathrm{mmol})$ in $1 \mathrm{~N} \mathrm{HCl}$-acetic acid solution $(0.02 \mathrm{~mL})$ was stirred at $25^{\circ} \mathrm{C}$ for $2 \mathrm{~h}$. After standing for 1 day, the reaction mixture was treated with cold water in the presence of a small amount of methanol, filtered, and washed with cold water to produce BHCP $(65.9 \mathrm{mg})$ in $56.9 \%$ yield. BHCP was identified by spectroscopic methods, including ${ }^{1} \mathrm{H}$ and ${ }^{13} \mathrm{C}-\mathrm{NMR}$, as well as by comparison with published spectral data and Thin Layer Chromatography (TLC) analysis [19]. The structure is shown in Figure 1.

BHCP: yellow amorphous powder $\left(\mathrm{CHCl}_{3}\right) ;{ }^{1} \mathrm{H}-\mathrm{NMR}\left(500 \mathrm{MHz}, \mathrm{DMSO}-d_{6}\right) \delta: 9.25(\mathrm{~s}, 2 \mathrm{H}, 2 \times \mathrm{OH})$, $7.28(\mathrm{~s}, 2 \mathrm{H}, 2 \times$ vinylic $\mathrm{H}), 7.14(\mathrm{~d}, 2 \mathrm{H}, J=2.0 \mathrm{~Hz}, 2 \times 2-\mathrm{H}), 7.11(\mathrm{dd}, 2 \mathrm{H}, J=8.5,2.0 \mathrm{~Hz}, 2 \times 6-\mathrm{H})$, $7.01(\mathrm{~d}, 2 \mathrm{H}, J=8.5 \mathrm{~Hz}, 2 \times 5-\mathrm{H}), \quad 3.81(\mathrm{~s}, 6 \mathrm{H}, 2 \times \mathrm{OMe}), \quad 3.01\left(\mathrm{~s}, 4 \mathrm{H}, 2 \times \mathrm{CH}_{2}\right) ;{ }^{13} \mathrm{C}-\mathrm{NMR}(100 \mathrm{MHz}$, DMSO-d 6 ) $\delta: 195.5,149.9,147.2,136.0,133.1,129.1,124.3,117.5,112.8,56.3,26.6$; ESI-MS: $m / z 351(\mathrm{M}-\mathrm{H})^{-}$.

\subsection{Inhibitory Effect of BHCP on Mushroom Tyrosinase Activity}

As shown in Table 1, BHCP inhibited tyrosinase with $\mathrm{IC}_{50}$ values of $1.10 \pm 0.12 \mu \mathrm{M}$ and $8.18 \pm 0.44 \mu \mathrm{M}$, whereas kojic acid (positive control) had $\mathrm{IC}_{50}$ values of $18.68 \pm 1.40 \mu \mathrm{M}$ and $33.89 \pm 1.16 \mu \mathrm{M}$ for monophenolase and diphenolase, respectively. In our previous study of synthetic potential inhibitors of tyrosinase, we found the mechanism through molecular modeling studies by which the 3-hydroxy and 4-methoxy groups of benzylidene had great binding tendencies towards the tyrosinase active site [20]. From this study result, it was shown that its functional groups (3-hydroxy and 4-methoxy groups) were associated with a significant increase in the tyrosinase inhibitory activity.

Table 1. Tyrosinase inhibitory activity and enzyme kinetic analysis of BHCP.

\begin{tabular}{|c|c|c|c|c|}
\hline & \multicolumn{2}{|c|}{ L-Tyrosine } & \multicolumn{2}{|c|}{ L-DOPA } \\
\hline & $\mathrm{IC}_{50}(\mu \mathrm{M})^{\mathrm{a}}$ & $\begin{array}{c}\text { Inhibition Type } \\
\left(K_{i}, \mu M\right)^{c}\end{array}$ & $\mathrm{IC}_{50}(\mu \mathrm{M})^{\mathrm{a}}$ & $\begin{array}{c}\text { Inhibition Type } \\
\left(K_{i}, \mu M\right)^{c}\end{array}$ \\
\hline $\mathrm{BHCP}$ & $1.10 \pm 0.12$ & Competitive (1.75) & $8.18 \pm 0.44$ & Competitive (10.5) \\
\hline Kojic acid ${ }^{d}$ & $18.68 \pm 1.40$ & Not tested & $33.89 \pm 1.16$ & Not tested \\
\hline
\end{tabular}

Furthermore, the mechanism responsible for tyrosinase inhibition by BHCP was investigated by enzyme kinetic analysis in the present study (Table 1 and Figure 2). Lineweaver-Burk plots were drawn using the data obtained from the kinetic studies, and the inhibition constant $\left(K_{\mathrm{i}}\right)$ was obtained from the Dixon plots. The Lineweaver-Burk double reciprocal plots indicated competitive-type inhibition. As shown in Figure $2 \mathrm{a}-\mathrm{c}, \mathrm{BHCP}$ acted as a competitive inhibitor of both L-tyrosine and L-DOPA. Moreover, intercepts on the $x$-axis of Dixon plots are commonly used to determine the types of enzyme inhibition constants $\left(K_{i}\right)$ for an enzyme-inhibitor complex [21,22], where the value of the $x$-axis indicates the value of $-K_{\mathrm{i}}$. As depicted in Figure $2 \mathrm{~b}-\mathrm{d}$, the $K_{\mathrm{i}}$ values of BHCP were $1.7 \mu \mathrm{M}$ and $10.5 \mu \mathrm{M}$ as substrates for L-tyrosine and L-DOPA, respectively. As the $K_{\mathrm{i}}$ value represents the concentration required to form an enzyme-inhibitor complex, a lower $K_{i}$ value suggests more effective inhibition against tyrosinase. 
(a)

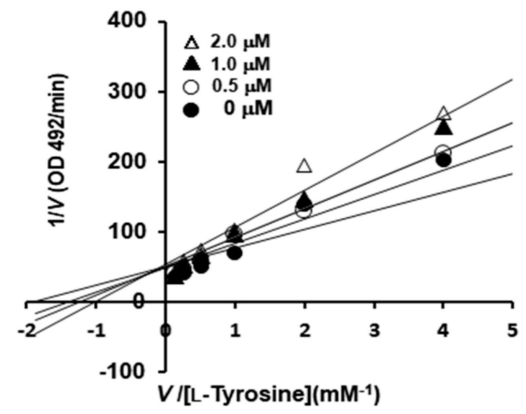

(c)

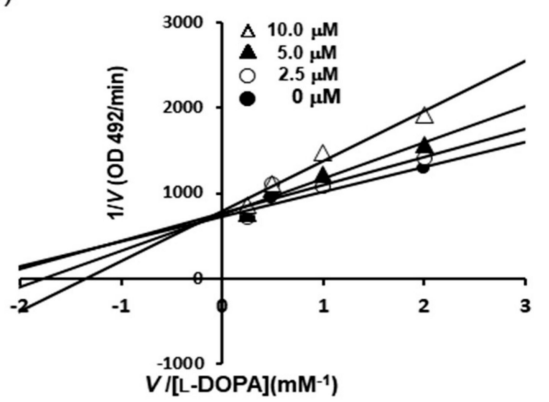

(b)

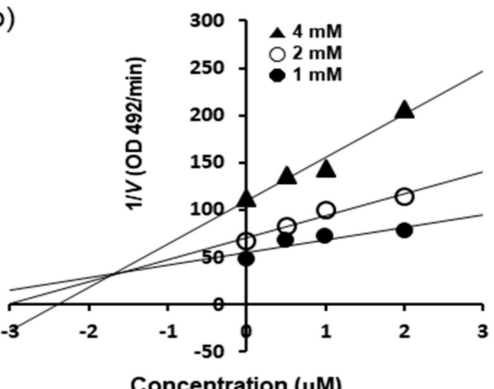

(d)

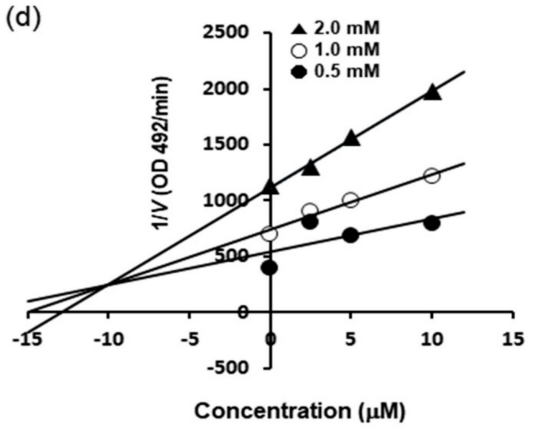

Figure 2. Lineweaver-Burk $(\mathbf{a}, \mathbf{c})$ and Dixon $(\mathbf{b}, \mathbf{d})$ plots for tyrosinase enzyme inhibition by BHCP. Tyrosinase inhibition was analyzed in the presence of different sample concentrations as follows: $0 \mu \mathrm{M}$ (filled circles), $0.5 \mu \mathrm{M}$ (open circles), $1 \mu \mathrm{M}$ (filled triangles), and $2 \mu \mathrm{M}$ (open triangles) (a); and effect in the presence of different concentrations of substrate (L-tyrosine): $1 \mathrm{mM}$ (filled circles), $2 \mathrm{mM}$ (open circles), and $4 \mathrm{mM}$ (filled triangles) (b); Tyrosinase inhibition was analyzed in the presence of different sample concentrations as follows: $0 \mu \mathrm{M}$ (filled circles), $2.5 \mu \mathrm{M}$ (open circles), $5 \mu \mathrm{M}$ (filled triangles), and $10 \mu \mathrm{M}$ (open triangles) (c); and effect in the presence of different concentrations of substrate (L-DOPA): $0.5 \mathrm{mM}$ (filled circles), $1.0 \mathrm{mM}$ (open circles), and $2.0 \mathrm{mM}$ (filled triangles) (d).

\subsection{Effects of BHCP on the Cell Viability of B16F10 Melanoma and Hs27 Fibroblast Cells}

Before determining whether BHCP exerted any anti-melanogenesis and anti-wrinkle activities, we examined the cytotoxicity of BHCP to B16F10 cells and Hs27 cells by treatment with different concentrations of BHCP for different time intervals, and cell viability was measured with the EZ-Cytox assay. As shown in Figure 3a,b, up to $10 \mu \mathrm{M}$ of BHCP for $48 \mathrm{~h}$ did not reduce the survival of either the B16F10 cells or Hs27 cells. Subsequently, further in vitro studies on the anti-melanogenesis and anti-wrinkle activities of BHCP were conducted with 1,5, and $10 \mu \mathrm{M}$.

(a)

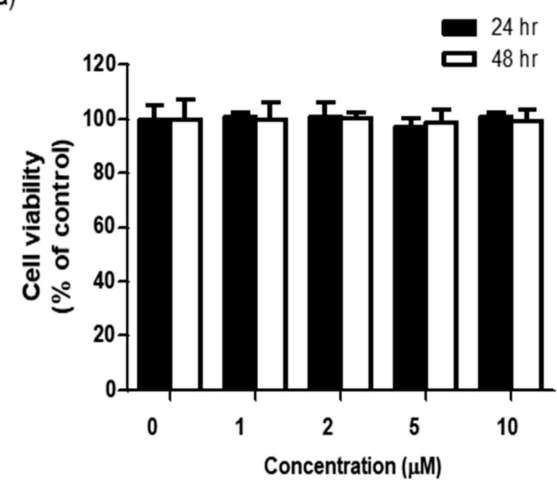

(b)

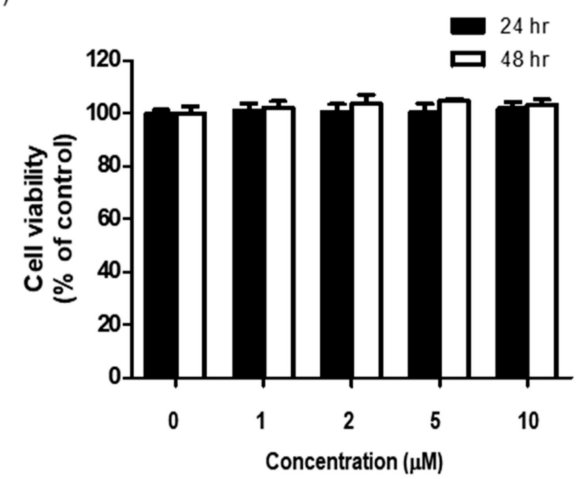

Figure 3. Cell viability of BHCP on B16F10 melanoma (a) and Hs27 fibroblast cells (b). Cells were treated with various concentrations $(0-10 \mu \mathrm{M})$ of BHCP for $24 \mathrm{~h}$ and $48 \mathrm{~h}$, respectively, and cell viability was measured by EZ-Cytox assay. 


\subsection{Inhibition of BHCP against Melanin Content and Cellular Tyrosinase Activity in B16F10 Melanoma Cells}

To determine whether BHCP exerts inhibitory potential on the melanin content of $\alpha$-MSH-induced B16F10 cells, cells were pretreated with the indicated different concentrations $(1,5$, and $10 \mu \mathrm{M})$ of BHCP or kojic acid $(5 \mathrm{mM})$ for $24 \mathrm{~h}$ and then stimulated with $\alpha$-MSH for $48 \mathrm{~h}$. As shown in Figure $4 \mathrm{a}$, the melanin content in the cells treated with BHCP in the presence of $\alpha$-MSH decreased in a concentration-dependent manner, showing $113 \%$ at $1 \mu \mathrm{M}, 106 \%$ at $5 \mu \mathrm{M}$, and $102 \%$ at $10 \mu \mathrm{M}$, compared to the control group treated with $\alpha$-MSH only $(186 \%)$. Interestingly, BHCP $(1 \mu \mathrm{M})$ inhibited melanin content more strongly than kojic acid $(5 \mathrm{mM})$. Furthermore, a cellular tyrosinase activity assay was performed to measure the inhibitory effect of BHCP on B16F10 cells. As shown in Figure 4b, $\mathrm{BHCP}$ decreased in a concentration-dependent manner with the tyrosinase activity by $120 \%$ at $1 \mu \mathrm{M}$, $116 \%$ at $5 \mu \mathrm{M}$, and $105 \%$ at $10 \mu \mathrm{M}$, compared to the control group treated with $\alpha-\mathrm{MSH}$ only (181\%). The inhibitory effect of BHCP was much more potent than that of kojic acid; the inhibition of BHCP at $1 \mu \mathrm{M}$ was superior to that of kojic acid at $5 \mathrm{mM}(131 \%)$. These results suggest that BHCP has a whitening effect by inhibiting melanin biosynthesis and intracellular tyrosinase synthesis in B16F10 melanocytes.

(a)

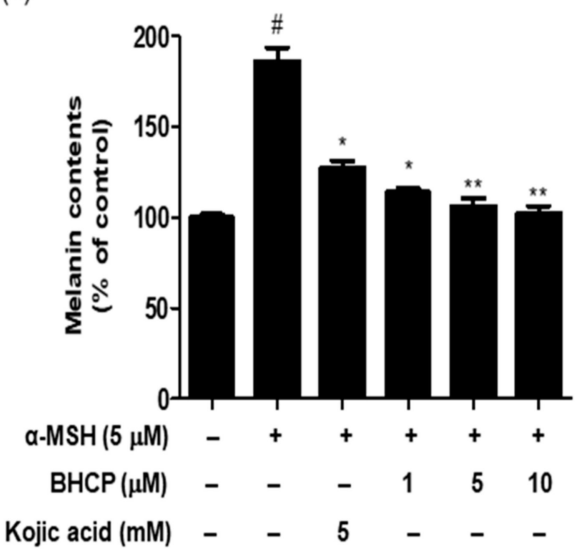

(b)

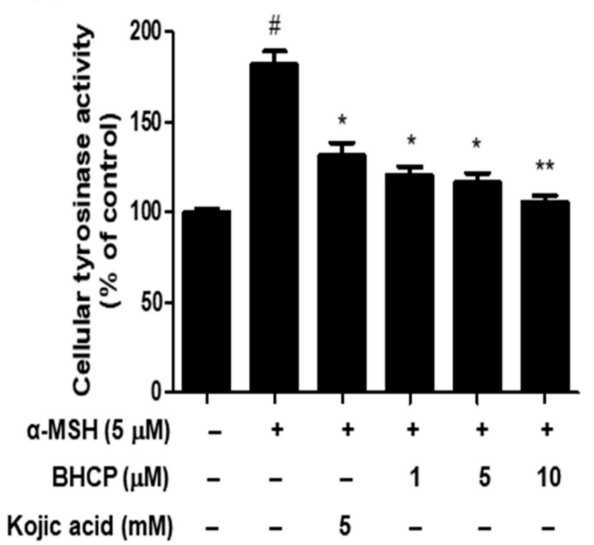

Figure 4. Inhibition of melanin contents (a) and cellular tyrosinase activity (b) of BHCP on B16F10 melanoma cells. Cells were preincubated with various concentrations $(1 \mu \mathrm{M}, 5 \mu \mathrm{M}$, and $10 \mu \mathrm{M})$ of $\mathrm{BHCP}$ or kojic acid $(5 \mathrm{mM})$ for $24 \mathrm{~h}$ and then stimulated with $\alpha$-MSH $(5 \mu \mathrm{M})$ for $48 \mathrm{~h}$. Melanin content of the pellet was evaluated at $405 \mathrm{~nm}$ (a); intracellular tyrosinase activity was determined with L-DOPA as the substrate, and the absorbance of L-DOPA chrome was read at $492 \mathrm{~nm}(\mathbf{b})$. Data are expressed as mean \pm S.E.M of three independent experiments. One-way ANOVA was used to determine the significances of differences: ${ }^{\#} p<0.05$ compared to the control group without $\alpha$-MSH treatment. ** $p<0.01$ and * $p<0.05$ compared to the $\alpha$-MSH-treated control group.

\subsection{Effects of BHCP on the Expression of MITF/Tyrosinase and Phosphorylated CREB in B16F10 Cells}

MITF, a specific transcription factor, plays a pivotal role in effectively activating the melanogenic genes, including tyrosinase, catalyzing the rate-limiting step in melanin biosynthesis: TRP-1, and TRP-2. The expression of MITF could be increased by the phosphorylation of CREB [23]. CREB is an important MITF promoter [24,25], and the phosphorylation of CREB in melanocytes increases MITF expression by binding to the CREB (c-AMP response element-binding protein) in melanocytes [26]. To elucidate the molecular pathways responsible for the anti-melanogenic effect of BHCP on B16F10 cells, we examined the protein levels of key molecules, including CREB and MITF, that play important roles in melanogenesis by Western blot analysis. The cells were treated with BHCP or kojic acid and then stimulated by $\alpha-\mathrm{MSH}$ for $48 \mathrm{~h}$. The time interval for the measurements followed the methodology described in previous studies [27]. As shown in Figure 5, tyrosinase and MITF levels increased with $\alpha$-MSH, but BHCP decreased these protein levels. Furthermore, phosphorylation of CREB was significantly suppressed by BHCP. The regulation of $\alpha-\mathrm{MSH}$-induced CREB phosphorylation 
is known to be potentially important in regulating pigmentation [28]. These results indicate that the anti-melanogenic effects of BHCP result from the downregulation of MITF and tyrosinase via the downregulation of phosphorylated CREB. The present study suggests that the elucidation of the inhibition mechanism of BHCP on tyrosinase and melanogenesis is crucial and must be further investigated in the future. Although the B16F10 melanoma cell line is generally more suitable for investigating signaling mechanisms in vitro, the B16F10 cell line is of a rodent melanoma. Therefore, further studies on human melanocytes will be necessary to confirm the findings.

(a)

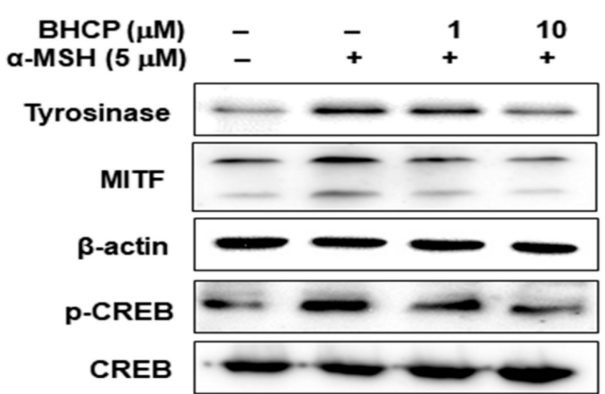

(c)

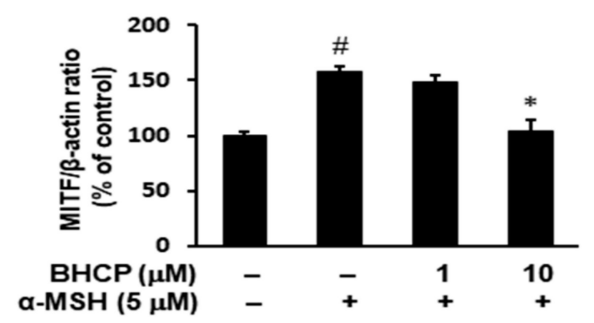

(b)

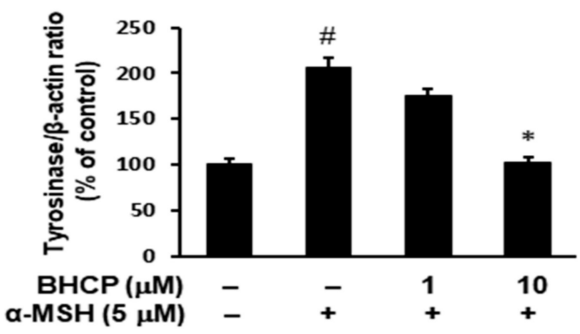

(d)

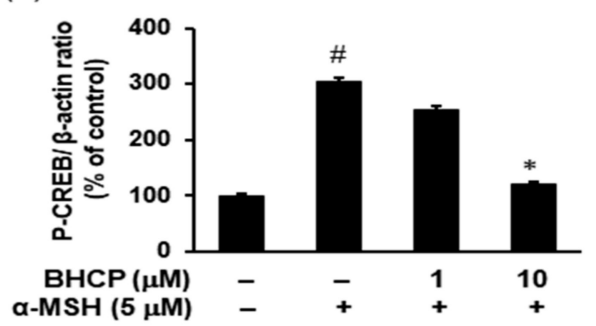

Figure 5. Effects of BHCP on the expression levels of phosphorylation of CREB, MITF, and tyrosinase in $\alpha$-MSH-stimulated B16F10 melanoma cells. Cells were preincubated with or without 1 and $10 \mu \mathrm{M}$ BHCP for $24 \mathrm{~h}$ and were stimulated with $\alpha$-MSH $(5 \mu \mathrm{M})$ for an additional $48 \mathrm{~h}$. Harvested cells were lysed and then examined for the expression levels of p-CREB, CREB, MITF, and tyrosinase by Western blotting (a); The protein levels of tyrosinase (b); MITF (c); and p-CREB (d) were quantitated with CS analyzer software. Tyrosinase, MITF, and p-CREB protein levels were normalized by $\beta$-actin. Data are expressed as mean \pm S.E.M. of three independent experiments. ${ }^{\#} p<0.05$ versus untreated control; ${ }^{*} p<0.05$ versus $\alpha-\mathrm{MSH}$ stimulation.

\subsection{Effect of BHCP on UV-Induced NF-kB p-p65 Activation in Hs27 Cells}

We next investigated the effect of BHCP on UV-induced expression of inflammatory mediators using Hs27 fibroblasts. It has been reported previously that the phosphorylation of p65 (Ser536) is essential for its capacity to transactivate genes [29]. Therefore, the protein levels of p-p65 (Ser536) and p65 were examined in the nucleus fraction by Western blotting. As indicated in Figure 6a,b, in Hs27 cells, UV increased the protein levels of p-p65 (Ser536) in the nucleus, whereas treatment of BHCP decreased the nucleus p-p65 (Ser536) protein levels. Correspondingly, the total amount of p65 was decreased in the cytoplasm by UV and restored by BHCP (Figure 6c,d). Although the protein expression levels of p65 were decreased in the cytoplasm and increased in the nucleus after UV induction, pretreatment with BHCP reversed these trends in a dose-dependent manner. Thus, these results suggest that the inhibition of p-p65 by BHCP might contribute to the protective effects on skin pigmentation and collagen destruction against UV. 
(a)

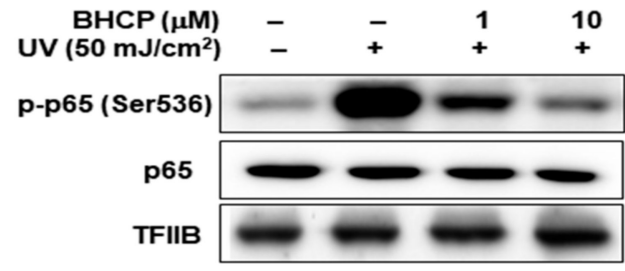

(c)

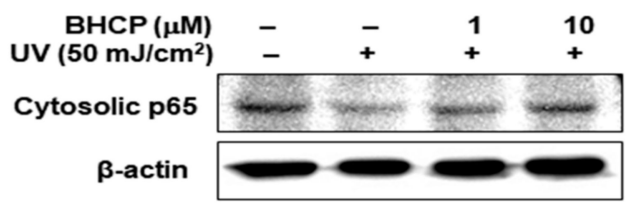

(b)

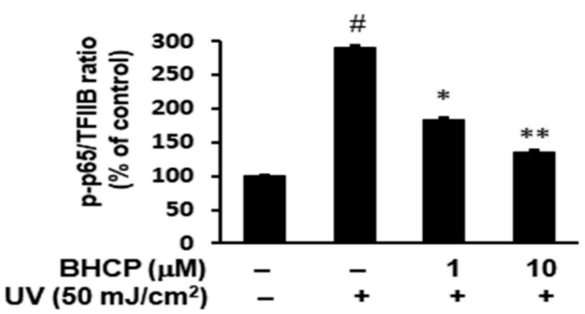

(d)

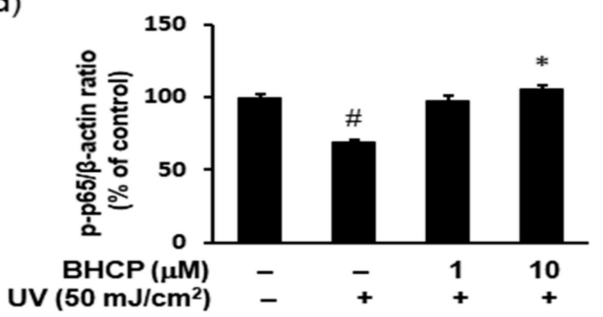

Figure 6. Effects of BHCP on the expression levels of p-p65 (Ser536) in UV-induced Hs27 human fibroblast cells. Cells were preincubated with or without 1 and $10 \mu \mathrm{M}$ BHCP for $24 \mathrm{~h}$ and were stimulated with UV $\left(50 \mathrm{~mJ} / \mathrm{cm}^{2}\right)$ for an additional $24 \mathrm{~h}$. Nuclear protein levels of p-p65 (Ser536) were determined by Western blotting (a); After normalization to TFIIB, relative ratios were quantitated with CS analyzer software (b); Cytosol protein levels of p65 was determined by Western blotting (c); After normalization to $\beta$-actin, ratios were quantitated with CS analyzer software (d). Data are expressed as mean \pm S.E.M. of three independent experiments. ${ }^{\#} p<0.05$ versus untreated control; ${ }^{*} p<0.05$ and ${ }^{* *} p<0.01$ versus $\alpha$-MSH stimulation.

\subsection{Effect of BHCP on the Expression of MMPs in Hs27 Cells}

MMPs play a vital role in skin aging. UV irradiation alters the connective tissues of the skin by upregulating the expression of MMPs [30,31]. MMP-1 is a collagen-decomposing enzyme that accelerates the breakdown of collagen synthesized from type I procollagen. MMP-9 is a gelatin-decomposing enzyme that breaks down collagen fibers cut by MMP-1, increasing wrinkle production and elasticity loss. To examine the anti-wrinkle effect of BHCP against UV induction, we determined the levels of MMP-1 and MMP-9 protein by Western blotting. Furthermore, UV-induced cells showed significantly elevated level of MMP-13, which initiates the degradation of type I and III collagen instead of MMP-1 [32]. We investigated the increase of MMPs (MMP1, MMP9, MMP12, and MMP13) after treatment of UV-induced Hs27 cells with BHCP at 1 and $10 \mu \mathrm{M}$. As shown in Figure 7, levels of MMP-1, MMP-9, MMP-12, and MMP-13 expression increased after UV induction; however, BHCP treatment decreased expression in a dose-dependent manner. Our results suggest that BHCP might contribute to the prevention of wrinkle formation by reducing the abnormal production of MMPs induced by UV exposure. These results imply that BHCP inhibits MMP expression in Hs27 fibroblasts to prevent collagen decomposition, and thus wrinkle production. Therefore, BHCP exhibits the potential for use as a preventive and treatment drug of skin-related disease. 
(b)

(a)

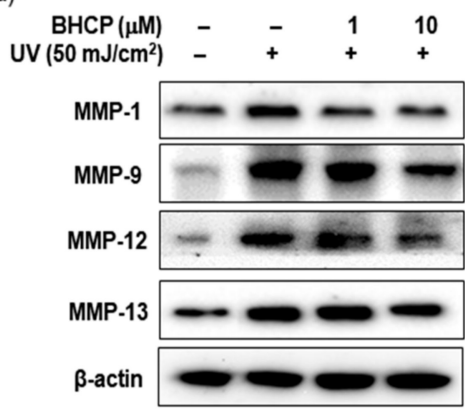

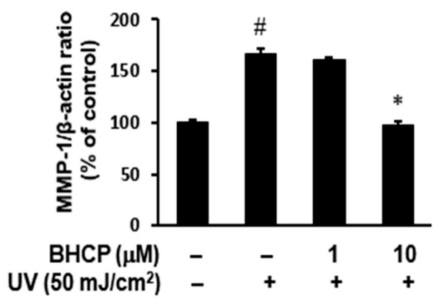

(d)

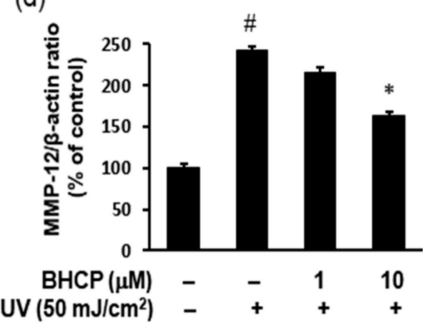

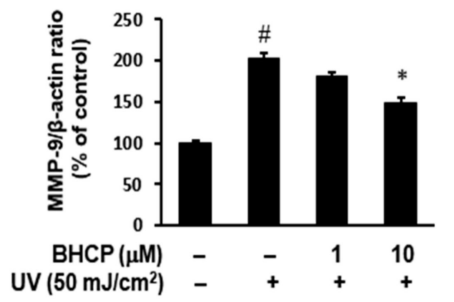

(e)

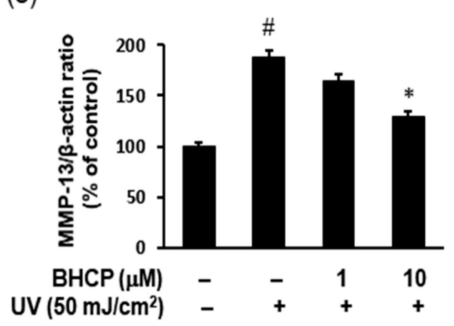

Figure 7. Effects of BHCP on the expression levels of MMP-1, MMP-9, MMP-12, and MMP-13 in UV-induced Hs27 human fibroblast cells. Cells were preincubated with or without 1 and $10 \mu \mathrm{M}$ BHCP for $24 \mathrm{~h}$ and were stimulated with UV $\left(50 \mathrm{~mJ} / \mathrm{cm}^{2}\right)$ for an additional $24 \mathrm{~h}$. Harvested cells were lysed and then examined for the expression levels of MMP-1, MMP-9, MMP-12, and MMP-13 by Western blotting (a); The protein levels of MMP-1 (b); MMP-9 (c); MMP-12 (d); and MMP-13 (e) were quantitated with CS analyzer software. MMP-1, MMP-9, MMP-12, and MMP-13 protein levels were normalized by $\beta$-actin. Data are expressed as mean \pm S.E.M. of three independent experiments. ${ }^{\#} p<0.05$ versus untreated control; ${ }^{*} p<0.05$ versus UV stimulation.

\section{Material and Methods}

\subsection{Chemicals and Instrumentation}

Mushroom tyrosinase (EC 1.14.18.1), $\alpha$-MSH, L-tyrosine, 3,4-dihydroxyphenylalanine (L-DOPA), dimethyl sulfoxide (DMSO), and kojic acid were purchased from Sigma-Aldrich (St. Louis, MO, USA). Dulbecco's modified Eagle's medium (DMEM), fetal bovine serum, streptomycin, and amphotericin were purchased from Gibco Life Technologies Inc. (Carlsbad, CA, USA). Antibodies against MITF, CREB, p-CREB, p-p65 (Ser536), p65, tyrosinase, MMP-1, MMP-9, MMP-12, MMP-13, TFIIB, and $\beta$-actin were purchased from Santa Cruz Biotechnology (Santa Cruz, CA, USA). Polyvinylidene difluoride (PVDF) membranes were obtained from the Millipore Corporation (Bedford, MA, USA). Sterile plastic ware for tissue cultures was purchased from SPL Labware (Seoul, Korea). The UV light source was provided by the Crosslinker 800 series (UVP, CA, USA) 6 lamp unit ( 8 watts/lamp). Thin-layer chromatography and silica gel 60 (mesh 230-400) were performed on silica gel $\mathrm{F}_{254}$-precoated plates from Merck Millipore (Darmstadt, Germany). NMR spectra were recorded using a Varian Unity INOVA $400\left(400 \mathrm{MHz}\right.$ for ${ }^{1} \mathrm{H}, 100 \mathrm{MHz}$ for $\left.{ }^{13} \mathrm{C}\right)$ and Varian Unity AS $500(500 \mathrm{MHz}$ for ${ }^{1} \mathrm{H}$ ) instruments. Chemical shift values $(\delta)$ are reported with reference to the respective residual solvent or deuterated peaks ( $\delta_{\mathrm{H}} 2.50$ and $\delta_{\mathrm{C}} 39.51$ for DMSO). Low-resolution mass spectrometry data were obtained with an Expression CMS mass spectrometer (Advion, Ithaca, NY, USA).

\subsection{Mushroom Tyrosinase Inhibition Assay}

Mushroom tyrosinase inhibitory activity was determined using both L-tyrosine and L-DOPA as substrates, based on the procedure described by Jung et al. [23]. Briefly, $190 \mu \mathrm{L}$ of tyrosinase enzyme (1000 U diluted with mushroom tyrosinase buffer, including $1 \mathrm{mM}$ L-tyrosine and L-DOPA solution) was added, in the presence or absence of compounds (final concentration ranging from 1 to $20 \mu \mathrm{M}$, dissolved in $100 \%$ DMSO), to each well of a 96-well plate, to provide a final volume of $200 \mu \mathrm{L}$. The plate 
was incubated at $37^{\circ} \mathrm{C}$ for $30 \mathrm{~min}$. Tyrosinase activity was quantified by measuring the absorbance at $492 \mathrm{~nm}$ using a microplate reader (TECAN, Salzburg, Austria) and the percentage inhibition (\%) was obtained from the following equation:

$$
\% \text { inhibition }=(\mathrm{Ac}-\mathrm{As}) / \mathrm{Ac} \times 100,
$$

where $\mathrm{Ac}$ is the absorbance of the control and $\mathrm{As}$ is the absorbance of the sample. The $\mathrm{IC}_{50}$ values were calculated from the log-linear curves and their equations. Average results for three determinations are shown. Kojic acid was used as a positive control.

\subsection{Kinetic Analysis of Tyrosinase Inhibition}

To determine the kinetic mechanisms, two kinetic methods (Lineweaver-Burk and Dixon plots) were complementarily used [21,22,33]. For the Lineweaver-Burk double reciprocal plots (a plot of 1 /enzyme velocity $(1 / V)$ versus 1 /substrate concentration $(1 /[\mathrm{S}]))$, the inhibition type was determined using various concentrations of L-tyrosine $(1,2$, and $4 \mathrm{mM})$ and L-DOPA $(0.5,1$, and $2 \mathrm{mM})$ as substrates in the presence of different concentrations of BHCP. The concentrations of BHCP were as follows: $0,0.5,1.0$, and $2.0 \mu \mathrm{M}$ for L-tyrosine; and $0,2.5,5$, and $10 \mu \mathrm{M}$ for L-DOPA. The Dixon plot is a graphical method (plot of 1 /enzyme velocity $(1 / V)$ against inhibitor concentration (I)) for the determination of the type of enzyme inhibition and was used to determine the dissociation constant or $K_{\mathrm{i}}$ for the enzyme-inhibitor complex. Dixon plots (single reciprocal plots) of the inhibition were obtained in the presence of L-tyrosine substrate at 1,2, and $4 \mathrm{mM}$ and $0,0.5,1.0$, and $2.0 \mu \mathrm{M}$ for BHCP; and L-DOPA substrate at $0.5,1.0$, and $2.0 \mathrm{mM}$ and $0,2.5,5.0$, and $10.0 \mu \mathrm{M}$ for BHCP.

\subsection{Cell Lines and Cell Culture}

Murine B16F10 melanoma cells were obtained from the Korean Cell Line Bank. The human skin fibroblast cell line Hs27 was purchased from the American Type Culture Collection (ATCC, Manassas, VA, USA). These cells were maintained in DMEM supplemented with 10\% fetal bovine serum, $100 \mathrm{U} / \mathrm{mL}$ penicillin, and $100 \mathrm{mg} / \mathrm{mL}$ streptomycin in a humidified $5 \% \mathrm{CO}_{2}$ incubator at $37^{\circ} \mathrm{C}$. Dermal fibroblasts on a $100 \mathrm{~mm}$ dish were treated with BHCP and exposed to $50 \mathrm{~mJ} / \mathrm{cm}^{2}$ UV in serum-free DMEM (UV light source, UVP). The Hs27 cells were cultured to 70-80\% confluence in a $100 \mathrm{~mm}$ diameter plate and were used between passage numbers 5 and 15.

\subsection{Cell Viability Assay}

The viability of cells was assessed using the EZ-Cytox kit assay. In brief, B16F10 cells and Hs27 fibroblasts were seeded into a 96-well plate at a density of $1 \times 10^{4}$ cells / well and incubated at $37^{\circ} \mathrm{C}$ for $24 \mathrm{~h}$. The cells were fed fresh, serum-free DMEM that contained different concentrations $(0,1,2,5$, and $10 \mu \mathrm{M}$ ) of BHCP, and incubated for 24 and $48 \mathrm{~h}$. Subsequently, $10 \mu \mathrm{L}$ of EZ-Cytox solution was loaded into each well and the cells were incubated for 2-4 h. The absorbance measurement of cells in the absence of any treatment was regarded as 100\% cell survival. Each treatment was performed in triplicate and each experiment was repeated three times.

\subsection{Determination of Melanin Contents Assay}

The effect of BHCP on $\alpha$-MSH-induced melanogenesis in B16F10 cells was based on a previously used method with slight modifications [34]. Briefly, B16F10 cells $\left(5 \times 10^{4}\right.$ cells /well $)$ in 6 -well plates were allowed to grow to $70-80 \%$ confluence. The cells were then treated with different concentrations of BHCP $(1,5$, and $10 \mu \mathrm{M})$ or kojic acid $(5 \mathrm{mM})$ for $24 \mathrm{~h}$, and then stimulated with $\alpha$-MSH $(5 \mu \mathrm{M})$ for $48 \mathrm{~h}$. After treatment, the cells were washed twice with ice-cold PBS, dissolved in $90 \mu \mathrm{L} 1 \mathrm{M} \mathrm{NaOH}$ solution including DMSO (5\%) at $60{ }^{\circ} \mathrm{C}$ for $1 \mathrm{~h}$, and the absorbance was measured at $405 \mathrm{~nm}$ with a microplate spectrophotometer (TECAN, Salzburg, Austria). To measure the amount of melanin in the experiment, the rate of inhibition in the treatment groups were calculated from the absorbance of 
the known concentrations of synthetic melanin, which were corrected to the total amount of protein that was present in the supernatant of the cell lysates. The absorbance of untreated cells was measured in triplicate.

\subsection{Cellular Tyrosinase Activity Assay}

Cellular tyrosinase activity assay was performed by measuring the rate of oxidation of L-DOPA [35]. B16F10 cells at a density of $5 \times 10^{4} /$ cells were placed in 6-well dishes and incubated overnight. The cells were then treated with various concentrations of $\mathrm{BHCP}(1,5$, and $10 \mu \mathrm{M})$ or kojic acid ( $5 \mathrm{mM})$ for $24 \mathrm{~h}$, and then stimulated with $\alpha$-MSH $(5 \mu \mathrm{M})$ for $48 \mathrm{~h}$. The cells were washed with PBS and lysed in a solution containing $100 \mu \mathrm{L}$ of $50 \mathrm{mM}$ phosphate buffer (pH 6.5), $0.1 \mathrm{mM}$ phenylmethylsulfonylfluoride (PMSF), and 1\% Triton X-100. Then, the cells were placed in a deep freezer machine $\left(-80{ }^{\circ} \mathrm{C}\right)$ for $30 \mathrm{~min}$. After defrosting the cells, the cellular extracts were purified by centrifugation at $12,000 \mathrm{rpm}$ for $30 \mathrm{~min}$ at $4{ }^{\circ} \mathrm{C}$. A total of $80 \mu \mathrm{L}$ the supernatant and $20 \mu \mathrm{L}$ of L-DOPA ( $2 \mathrm{mg} / \mathrm{mL}$ ) were added to a 96-well plate, and the absorbance at a wavelength of $492 \mathrm{~nm}$ was measured every 10 min during $1 \mathrm{~h}$ at $37^{\circ} \mathrm{C}$ with an ELISA plate reader (TECAN, Salzburg, Austria).

\subsection{Preparation of Cytosolic and Nuclear Extracts of Hs27 Cells}

The Hs27 cells were washed with ice-cold PBS and harvested. A buffer containing $10 \mathrm{mM}$ Tris ( $\mathrm{pH} 8.0$ ), $1.5 \mathrm{mM} \mathrm{MgCl} 2,1 \mathrm{mM}$ DTT, $0.1 \% \mathrm{NP}-40$, and protease inhibitors was used for the extraction of cytosolic fractions by centrifugation at $12,000 \mathrm{rpm}$ at $4{ }^{\circ} \mathrm{C}$ for $15 \mathrm{~min}$, and nuclear fractions were extracted from pellets using a buffer containing $10 \mathrm{mM}$ Tris, $50 \mathrm{mM} \mathrm{KCl}, 100 \mathrm{mM} \mathrm{NaCl}$, and protease inhibitors, incubated on ice for $30 \mathrm{~min}$, and then centrifuged at $13,000 \times \mathrm{g}$ for $30 \mathrm{~min}$ at $4{ }^{\circ} \mathrm{C}$ to obtain nuclear fractions.

\subsection{Western Blotting}

Lysate samples were boiled for $10 \mathrm{~min}$ in gel-loading buffer $(125 \mathrm{mM}$ Tris- $\mathrm{HCl}$, 4\% sodium dodecyl sulfate (SDS), 10\% 2-mercaptoethanol, and $0.2 \%$ bromophenol blue; $\mathrm{pH}$ 6.8) at a volume ratio of 1:1. The total protein equivalents for each sample were separated by SDS-polyacrylamide gel electrophoresis (PAGE) using acrylamide gels as based on the procedure described by Laemmli [36] and transferred to PVDF membranes at $80 \mathrm{~V}$ for $2 \mathrm{~h}$ using the wet-transfer system. The membranes were immediately placed into a blocking buffer (5\% nonfat milk) in $10 \mathrm{mM}$ Tris, pH 7.5, $100 \mathrm{mM}$ $\mathrm{NaCl}$, and $0.1 \%$ Tween-20. The blots were blocked to prevent nonspecific binding at $25^{\circ} \mathrm{C}$ for $2 \mathrm{~h}$. Subsequently, the membranes were incubated with a specific primary antibody at $4{ }^{\circ} \mathrm{C}$ overnight, followed by incubation with a horseradish peroxidase-conjugated secondary antibody at $25^{\circ} \mathrm{C}$ for $1 \mathrm{~h}$. Antibody labeling was detected by enhanced chemiluminescence in accordance with the manufacturer's instructions. Protein quantitation was performed using the Davinch-Chemi TM. Chemiluminescence Imaging System CAS-400SM (Core Bio, Seoul, Korea). Prestained protein markers were used for the determination of molecular weight.

\subsection{Statistical Analysis}

All data are presented as mean \pm S.E.M. The data were analyzed by one-way analysis of variance (ANOVA) for the differences between treatments followed by the Bonferroni post-hoc test. A value of $p<0.05$ was considered statistically significant.

\section{Conclusions}

In summary, the findings of the present study demonstrated that BHCP has a skin-whitening effect via inhibition of tyrosinase, which is a key enzyme for melanin biosynthesis in $\alpha$-MSH-induced B16F10 melanocytes. Furthermore, BHCP decreased the expression of MMP protein levels in UV-induced fibroblasts, which is expected to have an anti-wrinkle effect. Further research is required to confirm 
the whitening and anti-wrinkle effects of BHCP via animal and clinical studies. Finally, BHCP was identified to have both whitening and anti-wrinkle effects, indicating its potential for the development of therapeutic agents for diseases associated with hyperpigmentation and wrinkling.

Author Contributions: H.J.J. participated in the design of the study, performed the cell experiments, and wrote the manuscript. Y.J.P. and A.K.L. conceived the study and conducted interpretation of the data. S.L. and D.K. synthesized the compounds. H.Y.M. provided the synthetic compound and edited the manuscript. Y.S.J. and H.Y.J. made a critical revision of the manuscript. All authors have read and approved the final manuscript.

Funding: This research received no external funding.

Acknowledgments: This work was supported by a 2-Year Research Grant of Pusan National University.

Conflicts of Interest: The authors declare that they have no potential conflicts of interest with respect to the research, authorship, and/or publication of this manuscript.

\section{References}

1. Zhan, J.Y.; Wang, X.F.; Liu, Y.H.; Zhang, Z.B.; Wang, L.; Chen, J.N.; Huang, S.; Zeng, H.F.; Lai, X.P. Andrographolide sodium bisulfate prevents UV-induced skin photoaging through inhibiting oxidative stress and inflammation. Mediat. Inflamm. 2016, 2016, 3271451. [CrossRef] [PubMed]

2. Kim, J.; Lee, C.W.; Kim, E.K.; Lee, S.J.; Park, N.H.; Kim, H.S.; Kim, H.K.; Char, K.; Jang, Y.P.; Kim, J.W. Inhibition effect of Gynura procumbens extract on UV-B-induced matrix-metalloproteinase expression in human dermal fibroblasts. J. Ethnopharmacol. 2011, 137, 427-433. [CrossRef] [PubMed]

3. Chiang, H.M.; Chen, H.C.; Lin, T.J.; Shih, I.C.; Wen, K.C. Michelia alba extract attenuates UVB-induced expression of matrix metalloproteinases via MAP kinase pathway in human dermal fibroblasts. Food Chem. Toxicol. 2012, 50, 4260-4269. [CrossRef] [PubMed]

4. Hwang, E.; Park, S.Y.; Lee, H.J.; Lee, T.Y.; Sun, Z.W.; Yi, T.H. Gallic acid regulates skin photoaging in UVB-exposed fibroblast and hairless mice. Phytother. Res. 2014, 28, 1778-1788. [CrossRef] [PubMed]

5. Gupta, A.K.; Gover, M.D.; Nouri, K.; Taylor, S. The treatment of melasma: A review of clinical trials. J. Am. Acad. Dermatol. 2006, 55, 1048-1065. [CrossRef] [PubMed]

6. Whitaker, J.R. Principles of Enzymology for the Food Sciences, 2nd ed.; Marcel Dekker: New York, NY, USA, 1994; pp. 271-556.

7. Slominski, A.; Zmijewski, M.A.; Pawelek, J. L-Tyrosine and L-dihydroxyphenylalanine as hormone-like regulators of melanocyte functions. Pigment Cell Melanoma Res. 2012, 25, 14-27. [CrossRef] [PubMed]

8. Pifferi, P.G.; Baldassari, L.; Cultrera, R. Inhibition by carboxylic acids of an $o$-diphenol oxidase from Prunus avium fruits. J. Sci. Food Agric. 1974, 25, 263-270. [CrossRef] [PubMed]

9. Passi, S.; Nazzaro-Porro, M. Molecular basis of substrate and inhibitory specificity of tyrosinase: Phenolic compounds. Br. J. Dermatol. 1981, 104, 659-665. [CrossRef] [PubMed]

10. Maddodi, N.; Jayanthy, A.; Setaluri, V. Shining light on skin pigmentation: The darker and the brighter side of effects of UV radiation. Photochem. Photobiol. 2012, 88, 1075-1082. [CrossRef] [PubMed]

11. Wan, P.; Hu, Y.; He, L. Regulation of melanocyte pivotal transcription factor MITF by some other transcription factors. Mol. Cell Biochem. 2011, 354, 241-246. [CrossRef] [PubMed]

12. Inomata, S.; Matsunaga, Y.; Amano, S.; Takada, K.; Kobayashi, K.; Tsunenaga, M.; Nishiyama, T.; Kohno, Y.; Fukuda, M. Possible involvement of gelatinases in basement membrane damage and wrinkle formation in chronically ultraviolet B-exposed hairless mouse. J. Investig. Dermatol. 2003, 120, 128-134. [CrossRef] [PubMed]

13. Youssef, D.; Nichols, C.E.; Cameron, T.S.; Balzarini, J.; De Clercq, E.; Jha, A. Design, synthesis, and cytostatic activity of novel cyclic curcumin analogues. Bioorg. Med. Chem. Lett. 2007, 17, 5624-5629. [CrossRef] [PubMed]

14. Lee, K.H.; Ab Aziz, F.H.; Syahida, A.; Abas, F.; Shaari, K.; Israf, D.A.; Lajis, N.H. Synthesis and biological evaluation of curcumin-like diarylpentanoid analogues for anti-inflammatory, antioxidant and anti-tyrosinase activities. Eur. J. Med. Chem. 2009, 44, 3195-3200. [CrossRef] [PubMed]

15. Du, Z.Y.; Jiang, Y.F.; Tang, Z.K.; Mo, R.Q.; Xue, G.H.; Lu, Y.J.; Zheng, Z.; Dong, C.Z.; Zhang, K. Antioxidant and tyrosinase inhibition of polyphenolic curcumin analogs. Biosci. Biotechnol. Biochem. 2011, 75, 2351-2358. [CrossRef] [PubMed] 
16. Hosoya, T.; Nakata, A.; Yamasaki, F.; Abas, F.; Shaari, K.; Lajis, N.H.; Morita, H. Curcumin-like diarylpentanoid analogues as melanogenesis inhibitors. J. Nat. Med. 2012, 66, 166-176. [CrossRef] [PubMed]

17. Bukhari, S.N.; Jantan, I.; Unsal Tan, O.; Sher, M.; Naeem-Ul-Hassan, M.; Qin, H.L. Biological activity and molecular docking studies of curcumin-related $\alpha, \beta$-unsaturated carbonyl-based synthetic compounds as anticancer agents and mushroom tyrosinase inhibitors. J. Agric. Food Chem. 2014, 62, 5538-5547. [CrossRef] [PubMed]

18. Pan, Z.; Chen, C.; Zhou, Y.; Xu, F.; Xu, Y. Synthesis and cytotoxic evaluation of monocarbonyl analogs of curcumin as potential anti-tumor agents. Drug Dev. Res. 2016, 77, 43-49. [CrossRef] [PubMed]

19. Leow, P.C.; Bahety, P.; Boon, C.P.; Lee, C.Y.; Tan, K.L.; Yang, T.; Ee, P.L. Functionalized curcumin analogs as potent modulators of the Wnt/ $\beta$-catenin signaling pathway. Eur. J. Med. Chem. 2014, 71, 67-80. [CrossRef] [PubMed]

20. Jung, H.J.; Lee, M.J.; Park, Y.J.; Noh, S.G.; Lee, A.K.; Moon, K.M.; Lee, E.K.; Bang, E.J.; Park, Y.J.; Kim, S.J.; et al. A novel synthetic compound, (Z)-5-(3-hydroxy-4-methoxybenzylidene)-2-iminothiazolidin-4-one (MHY773) inhibits mushroom tyrosinase. Biosci. Biotechnol. Biochem. 2018, 82, 759-767. [CrossRef] [PubMed]

21. Dixon, M. The determination of enzyme inhibitor constants. Biochem. J. 1953, 55, 170-171. [CrossRef] [PubMed]

22. Cornish-Bowden, A.C. A simple graphical method for determining the inhibition constants of mixed, uncompetitive and non-competitive inhibitors. Biochem. J. 1974, 137, 143-144. [CrossRef] [PubMed]

23. Baek, S.H.; Lee, S.H. Sesamol decreases melanin biosynthesis in melanocyte cells and zebrafish: Possible involvement of MITF via the intracellular cAMP and p38/JNK signalling pathways. Exp. Dermatol. 2015, 24, 761-766. [CrossRef] [PubMed]

24. Jung, E.; Hwang, W.; Kim, S.; Kim, Y.S.; Kim, Y.S.; Lee, J.; Park, D. Depigmenting action of platycodin D depends on the cAMP/Rho-dependent signalling pathway. Exp. Dermatol. 2011, 20, 986-991. [CrossRef] [PubMed]

25. Kang, Y.G.; Choi, E.J.; Choi, Y.; Hwang, J.K. 5,7-Dimethoxyflavone induces melanogenesis in B16F10 melanoma cells through cAMP-dependent signalling. Exp. Dermatol. 2011, 20, 445-447. [CrossRef] [PubMed]

26. Saha, B.; Singh, S.K.; Sarkar, C.; Bera, R.; Ratha, J.; Tobin, D.J.; Bhadra, R. Activation of the Mitf promoter by lipid-stimulated activation of p38-stress signalling to CREB. Pigment Cell Res. 2006, 19, 595-605. [CrossRef] [PubMed]

27. Yen, F.L.; Wang, M.C.; Liang, C.J.; Ko, H.H.; Lee, C.W. Melanogenesis inhibitor(s) from Phyla nodiflora extract. Evid. Based Complement. Altern. Med. 2012, 2012, 867494. [CrossRef] [PubMed]

28. Zhou, J.; Ren, T.; Li, Y.; Cheng, A.; Xie, W.; Xu, L.; Peng, L.; Lin, J.; Lian, L.; Diao, Y.; et al. Oleoylethanolamide inhibits $\alpha$-melanocyte stimulating hormone-stimulated melanogenesis via ERK, Akt and CREB signaling pathways in B16 melanoma cells. Oncotarget 2017, 8, 56868-56879. [CrossRef] [PubMed]

29. Yang, F.; Tang, E.; Guan, K.; Wang, C.Y. IKK beta plays an essential role in the phosphorylation of RelA/p65 on serine 536 induced by lipopolysaccharide. J. Immunol. 2003, 170, 5630-5635. [CrossRef] [PubMed]

30. Vincenti, M.P.; White, L.A.; Schroen, D.J.; Benbow, U.; Brinckerhoff, C.E. Regulating expression of the gene for matrix metalloproteinase-1 (collagenase): Mechanisms that control enzyme activity, transcription, and mRNA stability. Crit. Rev. Eukaryot. Gene Expr. 1996, 6, 391-411. [CrossRef] [PubMed]

31. Stetler-Stevenson, W.G.; Yu, A.E. Proteases in invasion: Matrix metalloproteinases. Semin. Cancer Biol. 2001, 11, 143-152. [CrossRef] [PubMed]

32. Rittie, L.; Fisher, G.J. UV-light-induced signal cascades and skin aging. Ageing Res. Rev. 2002, 1, 705-720. [CrossRef]

33. Lineweaver, H.; Burk, D. The determination of enzyme dissociation constants. J. Am. Chem. Soc. 1934, 56, 658-666. [CrossRef]

34. Bilodeau, M.L.; Greulich, J.D.; Hullinger, R.L.; Bertolotto, C.; Ballotti, R.; Andrisani, O.M. BMP-2 stimulates tyrosinase gene expression and melanogenesis in differentiated melanocytes. Pigment Cell Res. 2001, 14, 328-336. [CrossRef] [PubMed] 
35. Kim, D.S.; Kim, S.Y.; Chung, J.H.; Kim, K.H.; Eun, H.C.; Park, K.C. Delayed ERK activation by ceramide reduces melanin synthesis in human melanocytes. Cell Signal. 2002, 14, 779-785. [CrossRef]

36. Laemmli, U.K. Cleavage of structural proteins during the assembly of the head of bacteriophage T4. Nature 1970, 227, 680-685. [CrossRef] [PubMed]

Availability: Sample of the BHCP is available from the authors. 